University of California, Hastings College of the Law UC Hastings Scholarship Repository

Faculty Scholarship

2012

\title{
Measuring, Monitoring, Reporting, and Verifying (MMRV): Negotiating Trust in Transnational Contracts for REDD,
}

David Takacs

UC Hastings College of the Law, takacsd@uchastings.edu

Follow this and additional works at: http://repository.uchastings.edu/faculty_scholarship

Part of the Contracts Commons, and the International Law Commons

\section{Recommended Citation}

David Takacs, Measuring, Monitoring, Reporting, and Verifying (MMRV): Negotiating Trust in Transnational Contracts for REDD,, 106 Am. Soc'y Int'l L. Proc. 518 (2012).

Available at: http://repository.uchastings.edu/faculty_scholarship/1263

This Article is brought to you for free and open access by UC Hastings Scholarship Repository. It has been accepted for inclusion in Faculty Scholarship by an authorized administrator of UC Hastings Scholarship Repository. For more information, please contact marcusc@uchastings.edu. 


\title{
Measuring, Monitoring, Reporting, and Verifying (MMRV): Negotiating Trust in Transnational Contracts for REDD+
}

\author{
By David Takacs*
}

Efforts to mitigate greenhouse gas build-up through quantifying and controlling the world's forests highlight new directions in international transnational conservation contracts. The emerging regime of Measuring, Monitoring, Reporting, and Verifying (MMRV) in global climate change cooperation, with a particular focus on Reducing Emissions from Deforestation and forest Degradation (REDD+), shows how transnational conservation contracts are helping to reconstruct "sovereignty" - a cornerstone of international law-to adapt to 21 st-century perils that demand unprecedented cooperation between nations.

While negotiating a Kyoto Protocol successor, Northern nations have pledged US\$30 billion in "fast track" mitigation aid to Southern nations between 2010-2012, and pledged US $\$ 100$ billion yearly by 2020 to support mitigation and adaptation activities in Southern nations. This is to be managed in a global "Green Fund" under the auspices of the World Bank. ${ }^{1}$

Despite opposition, ${ }^{2}$ REDD+ will attract a large proportion of these funds, as diverse stakeholders prize the South's dwindling forests. Tropical deforestation accounts for about $15-20 \%$ of GHG emissions-a greater contribution than all forms of transport combined, and equal to the annual emissions of China or the United States. ${ }^{3}$ Extant forests, now viewed as a repository of greenhouse gases fungible with industrialized emissions, have been brought under an international cross-boundary trading regime. ${ }^{4}$ Northern governments, businesses, and citizens are investing billions of dollars in the vast, imperiled forests of the South. ${ }^{5}$ Funds come not just from the UN Framework Convention on Climate Change (UNFCCC) architecture, but also from parallel, legally mandated offsetting programs in Norway (spending

\footnotetext{
* Associate Professor of Law, University of California, Hastings College of Law.

${ }^{1}$ Daniel Bodansky, A Tale of Two Architectures: The Once and Future U.N. Climate Change Regime (2011), available at http://papers.ssrn.com/sol3/papers.cfm?abstract_id=1773865. Mitigation refers to actions to decrease the amount of greenhouse gases in the atmosphere, either because we reduce the amount we emit, or we find natural or artificial "sinks" that store the GHGs before they reach the atmosphere. Adaptation refers to helping human and nonhuman communities develop resilience to the changes that global climate change will bring.

${ }^{2}$ E.g., Greenpeace, Carbon Scam: Noel Kempff Climate action Project and the Push for Sub-National FOREST OFFSETS (2009), at http://www.greenpeace.org/usa/Global/usa/report/2010/1/carbon-scam-noel-kempffclima.pdf; International. Rivers, Bad Deal for the Planet (2008); Greenpeace, The Economics of 2 Degrees Celsius ANd REDD (2009); Ann E. Prouty, The Clean Development Mechanism and lts Implications for Climate Justice, 34 Colum. J. Envtl. L. 513, 529 (2009); Kevin Smith, The Carbon Neutral Myth: OffSET INDULGENCES FOR YOUR CARBON SINS (2009), available at http://www.carbontradewatch.org/pubs/ carbon_neutral_myth.pdf; Larry Lohmann, Carbon Trading: A CRitical Conversation on Climate Change, Privatisation, and Power 230-33 (2006); Tom Griffiths, Seeing "Red"? "Avoided Deforestation" and THE Rights of INDigenous PEOPLes AND Local Communities 14 (2007), available at http://www.forestpeoples.org/sites/fpp/files/publication/2010/01/avoideddeforestationredjun07eng_0.pdf; DAviD HumPHREYS, LOGJAM: Deforestation and the Crisis of Global Governance 208 (2006); Sinkswatch, Climate Change: The Forest Connection, at http://www.sinkswatch.org/forX.html; see all of redd.monitor.org.

${ }^{3}$ United Nations Development Programme, Human Development Report 2007/2008: Fighting Climate Change: Human Solidarity in a Divided World 41 (2007); Lorenzo Cotula \& James Meyers, Tenure in ReDD: Start-Point OR AfTerThought? (2009); American Clean Energy and Security Act, H.R. $2454 \S \S 751-$ 756 (2009); § 752(2) 2011.

${ }^{4}$ William Boyd, Ways of Seeing in Environmental Law: How Deforestation Became an Object of Climate Governance, 37 EcoloGY L.Q. 843 (2010).

5 I use "North" to refer to developed or industrialized nations. Northern nations have been primarily responsible for creating the problems of global climate change through pollution associated with industrialization; Northern nations are thus the only nations with binding greenhouse gas reduction commitments under the Kyoto Protocol. "Southern" nations are those in the process of development; Southern nations are least responsible for creating global climate change, yet will suffer the most from its consequences.
} 
US $\$ 3$ billion on REDD+), California, and elsewhere, as well as a voluntary market where concerned citizens and businesses offset their GHG consumption through investing in REDD+ in developing nations. ${ }^{6}$

In a REDD+ project, an entity - a government, community, private developer, or individual landowner-commits to reforest land or to preserve a forest that would otherwise be cut down or degraded. The entity may then sell the carbon, now sequestered in the trees, for a contracted period of time. ${ }^{7}$ REDD+ may happen on a project-by-project basis-one developer, one landowner. Or REDD+ may happen on a broader scale, i.e., a nation or state/province pledges to use REDD+ funding to reduce deforestation or foment reforestation resulting in sequestered GHGs above a "business as usual" ' baseline. ${ }^{8}$ If REDD+ lived up to its synergistic potential, it would mitigate greenhouse gas buildup, alleviate rural poverty, and preserve biodiversity. ${ }^{9}$ To make this transfer of funds possible-and thus sustain tropical forests and the human and nonhuman communities that depend upon them-the acronym "MMRV" has become key to mutually beneficial transnational contracts. The acronym MRV first arose in the 2007 UNFCCC Conference of Parties: The Bali Action Plan called for MRV as a crucial element of any new international agreement. "'MMRV'" stands for "Measuring, Monitoring, Reporting, and Verifying." "' Without a comprehensive, rigorous, reciprocaland in many cases, intrusive-system of MMRV, it is unlikely that global leaders will invest in the Green Fund or find common will for a multilateral environmental agreement to succeed the Kyoto Protocol. ${ }^{12}$ Outside the formal UNFCCC process, investors in REDD+ are developing MMRV protocols to ensure multiple, synergistic returns on their investments. ${ }^{13}$

\section{MMRV OVERVIEW}

MMRV is key to forging transnational conservation contracts that use REDD+ to battle climate change, and simultaneously to staunch deforestation and reduce poverty. ${ }^{14}$ The precise parameters-who must meet which MMRV obligations, on what subjects, with what intrusive

\footnotetext{
${ }^{6}$ Christopher Joyce, Climate Strategists: To Cut Emissions, Focus on Forests, NPR, Dec. 10, 2011, http:// www.npr.org/2011/12/10/143454111/climate-activists-to-cut-emissions-focus-on-forests? $\mathrm{ft}=1 \& \mathrm{f}=1025$; Governors' Climate and Forests Task Force, http://www.gcftaskforce.org/; Press Release, Gov. Schwarzenegger Partners with Other States to Reduce Greenhouse Gas Emissions from Deforestation (Nov. 18, 2008); The REDD Offset Working Group, http://stateredd.org/about-row/; Norway Plans Record 2010 Carbon Capture Spending, REUTERS, Oct. $13,2009$.

${ }^{7}$ David Takacs, Forest Carbon: LaW + Property Rights 14 (2009) (providing details of various property arrangements for forest carbon).

${ }^{8}$ Jade Saunders, Johannes Ebeling \& Ruth Nussbaum, Reduced Emissions from Deforestation and Forest Degradation: Lessons from a Forest Governance Perspective 6 (2008), available at http://www.proforest.net/publication-objects/REDD\%20and\%20Governance.pdf.

${ }^{9}$ David Takacs, Forest Carbon Offsets and International Law: A Deep Equity Legal Analysis, 22 GeO. INT'L ENVTL. L. REv. 521, 523-24 (2010).

${ }^{10}$ United Nations Framework Convention on Climate Change (UNFCCC), Report of the Conference of the Parties on Its Thirteenth Session Held in Bali from 3 to 15 December 2007, UN Doc. FCCC/CP/2007/6/Add.1* (Mar. 14, 2008) [hereinafter Bali Action Plan].

11 The more common acronym is "MRV." The problem with that acronym is that sometimes "M" is for Measuring, sometimes for "Monitoring," and sometimes for both, even though they are not the same thing.

12 Jake Schmidt, Tracking Carbon with Transparency: Improving Accuracy and Accountability in the International Global Warming Agreement, Natural Resources Defense Council (2010), http://www.nrdc.org/globalwarming/files/ trackingcarbon-fs.pdf.

${ }^{13}$ E.g., Climate, Community \& Biodiversity Alliance (CCB), Climate, Community and Biodiversity Project Design Standards 4 (2d ed. 2008), available at http://www.climate-standards.org/standards/thestandards.html.

${ }^{14}$ David Hunter, Implications of the Copenhagen Accord for Global Climate Governance, 10 SUSTAINABLE DEv. L. \& POL'Y 4, 14 (2010).
} 
oversight-have been pivotal in negotiations to forge multilateral climate change cooperation. $^{15}$

"'You can't manage what you can't measure,' proclaims the World Resources Institute. ${ }^{16}$ An official U.S. submission to the UNFCCC states that MMRV provides the necessary "sunshine" to ensure all nations are fulfilling their pledges. ${ }^{17}$ All parties want others to undertake clear commitments and for all parties to be confident that everyone is making progress toward fulfilling these commitments. ${ }^{18}$ Northern donors and investors want to guarantee a return on their investments-that Southern governments and communities do what they say they will do, and that aid reaches the intended communities. Southern governments and communities want to ensure that Northern nations actually fulfill their pledges to reduce GHG emissions and deliver climate change mitigation and adaptation funding. Activists of many stripes want to ensure that investments safeguard and promote economic welfare, human rights, and biodiversity.

A "crisis of mistrust"' led to the diverse proposed MMRV requirements. ${ }^{19}$ Getting nations to agree to any arrangement would prove difficult, as the developing world continued to insist that the developed nations were and are primarily responsible for global climate change. Thus they should bear the burden both of mitigating GHG build-up and paying for developing nations to adapt. The developed nations, led by the United States, have been reluctant to accept any agreement that does not bind the developing world (particularly the booming economies of China, India, Brazil, and like nations) to share the burden of mandatory GHG reductions. ${ }^{20}$ Northern nations (especially the United States) were not about to accept Southern pledges without verification, and, according to Murray Ward, "based on a long history of under-delivery, developed countries were not to be trusted to provide adequate levels of support for such actions.",21

You can measure anything quantifiable (and if it's not inherently quantifiable, you can invent scales and gradients to make it so). For example, for REDD+, to "measure" forest carbon first means assessing the amount of carbon in a given area at a given time. ${ }^{22}$ To monitor is to assess the changes in carbon or any other variable over time. ${ }^{23}$ To report is to go public with what you have measured and monitored and thus permit others to see what you are doing. Successful reporting relies upon excellent measuring and monitoring, and some standardization of format that allows viewers of reported information to compare data;

${ }^{15}$ Id. at 14; Daniel Bodansky, The Copenhagen Climate Change Conference: A Postmortem, 104 AJIL 230, 236 (2010); Anne Arquit Niederberger \& Melinda Kimble, MRV Under the UN Climate Regime-Paper Tiger or Catalyst for Continual Improvement? 1 Greenhouse Gas Measurement \& MGMT. 47 (2011). See Suzanne Goldenberg, Cancún Climate Change Summit: America Plays Tough, Guardian, Nov. 30, 2010 (describing U.S. intransigence on developing-country inspections).

${ }^{16}$ Remi Moncel \& Kelly Levin, Transparency and Accountability (MRV) in the Durban Climate Deal, WRI INSIGHTS, Feb. 13, 2012, http://insights.wri.org/news/2012/02/transparency-and-accountability-mrv-durban-climate-deal.

${ }^{17}$ World Resources Institute, Summary of UNFCCC Submissions (APril 19, 2010-November 23, 2010), at 10, http://pdf.wri.org/working_papers/unfccc_submissions_summary_2010-11-23.pdf.

${ }^{18}$ Schmidt, supra note 12 , at 2.

${ }^{19}$ Murray Ward, To V or Not to V: That Is a Question (Oxford Energy \& Environment Comment) 1 (2010).

${ }^{20}$ Bodansky, supra note 15, at 233-34; John M. Broder, At Climate Talks, a Familiar Standoff Emerges Between the U.S. and China, N.Y. TimEs, Dec. 7, 2011.

${ }^{21}$ Ward, supra note 19 , at 1.

22 Terrestrial Carbon Group, Measuring and Monitoring Terrestrial Carbon as Part of "REDD+" MRV SYSTEMS 3, 10 (2009), http://www.theredddesk.org/sites/default/files/resources/pdf/2010/TCG_Policy_Brief_ 5_Measuring_and_Monitoring_Oct_09.pdf.

${ }^{23}$ Id. at 2 . 
it also allows other parties to learn from what you are doing. ${ }^{24}$ To verify is to ascertain independently that the information measured, monitored, and reported is accurate. ${ }^{25}$

As demands for MMRV spread, different voices call for at least six different regimes of MMRV in the global climate change regime in general, and for REDD+ assistance in particular. Comprehensive MMRV is being implemented, or proposed for:

- Carbon sequestered in the forests of the global South. REDD+ funds hinge on MMRV for deforestation and reforestation rates. For donor nations, this means instituting a system of MMRV to ensure that reforestation and deforestation efforts are successful, i.e., that the Southern nation or community plants new trees or preserves existing trees where it says it has. Remote sensing and other technologies have helped make tropical forests a controllable object of climate governance. Technologies allow remote observers to calculate the amount of carbon sequestered in an area - and thus ensure that forest carbon can be fungible with more easily calculated forms of industrial carbon pollution. ${ }^{26}$ Even with Google Earth or similar technologies, foot patrols back up the accuracy of the remotely sensed data, to make sure that the broad changes observed from on high dovetail with what is actually happening under the forest canopy. This level of scrutiny marks a noted incursion into a nation's sovereign territory. ${ }^{27}$

- Governance reforms, particularly with respect to forest governance, in the global South. Northern nations are also devising MMRV schemes for governance reforms. Various organizations - e.g., USAID, the World Bank-name performance indicators for good governance. ${ }^{28}$ That is to say, "governance," too, can be quantified and measured by entities seeking empirical assurance that their financial investments reach their intended destinations efficiently. Those calling for MMRV for governance do not lack justification: Among the reasons tropical forests are disappearing in the first place include poor or inadequate governance structures. ${ }^{29}$ Northern donors cite Southern government corruption problems, and seek assurances that a nation's elite will not arrogate REDD+ funds at the expense of the poor and the forests upon which they depend. These parameters traditionally fall within the purview of national governments. So, for example, when the UN-REDD Programme discusses its scope

\footnotetext{
${ }^{24}$ Clare Breidenich \& Daniel Bodansky, Measurement, Reporting and Verification in a Post-2012 Climate Agreement 5 (2009); Schmidt, supra note 12.

${ }^{25}$ Jørgen Wettestad, Monitoring and Verification, in THE OXFORD HANDBOOK OF INTERNATIONAL EN VIRONMENTAL LAw 974, 975 (Daniel Bodansky, Jutta Brunnée \& Ellen Hey eds., 2007); Ward, supra note 19.

${ }^{26}$ Boyd, supra note 4, at 853; William Boyd, Climate Change, Fragmentation, and the Challenges of Global Environmental Law: Elements of a Post-Copenhagen Assemblage, 32 U. PA. J. INT'L L. 457, 525 n.220 (2010).

27 Joyce, supra note 6 . Note that the more sophisticated this kind of technology becomes, the less the need for foot patrols, but the more intrusive (without national consent) the investigations from above.

${ }^{28}$ E.g., the World Bank, Worldwide Governance Indicators, http://info.worldbank.org/governance/wgi/index.asp; Daniel Kaufmann, Aart Kraay \& Massimo Mastruzzi, Governance Matters VIII: Aggregate and Individual Governance Indicators 1996-2008 (World Bank Development Research Group Policy Research Working Paper 4978, June 2009); Brenda Brito et al. A Draft Framework of Indicators for Assessing Governance of the Forest Sector (Governance of Forests Initiative Working Paper, Sept. 2009), http://pdf.wri.org/working_papers/ gfi_tenure_indicators_sep09.pdf.

${ }^{29}$ E.g., Carmenza Robledo, Jürgen Blaser, Sarah Byrne \& Kaspar Schmidt, Climate Change and GOVERNANCE IN THE FOREST SECTOR (2008), http://www.rightsandresources.org/documents/files/doc_857.pdf. For a review of where corruption is likely to emerge in REDD+, see Michael N. Brown, Limiting Corrupt Incentives in a Global REDD Regime, 37 EcologY L.Q. 237 (2010).
} 
of MMRV work to address " unenforced land tenure systems, elite capture, marginalization of stakeholders, uncoordinated mechanisms or corruption," 30 it is reaching deep into the traditional sovereign purview of nation states. To overcome sovereignty concerns requires delicate negotiations to enable external monitors to collect data and assess international governance structures, or to re-imagine what sovereignty means.

- Actual GHG reductions achieved in the global North and South. Under the UNFCCC/ $\mathrm{KP}$, thus far all nations have had to report on their GHG emissions and emissions reductions. Annex 1 nations (developed nations that take on formal GHG reduction commitments under the Kyoto Protocol) must report the quantity of their reductions, name the actual measures they have used to achieve those reductions, and have their results verified by expert teams. ${ }^{31}$ An electronic system tracks these national registries, with oversight from the UNFCCC secretariat. ${ }^{32}$ While some observers believe this system works well, ${ }^{33}$ it is not without its critics who advocate more frequent, more transparent, more reviewable, and more detailed MMRV. ${ }^{34}$ While the South is looking for more rigorous MMRV to ensure that the Northern nations are reducing as they say they are, the North is insisting that Southern nations be required for the first time to make emissions reduction pledges-particularly in the form of REDD+ offsetsand that they be monitored and verified. ${ }^{35}$

- Financial and technological support for Southern GHG reductions (particularly with respect to $R E D D+$ ). Developing nations are demanding MMRV for Northern financial and technical pledges, which they would then link to concomitant mitigation actions of their own. ${ }^{36}$ The Bali Action Plan named this in its call for "national appropriate mitigation actions ... supported and enabled by technology, financing and capacitybuilding, in a measurable reportable and verifiable manner." ${ }^{37}$ In recent negotiations, India and other Southern nations officially submitted requests that MMRV apply not just to GHG reduction actions, but to financial and technological support for such actions. ${ }^{38}$ Currently, developed nations are required to report financial resources they dedicate to helping developing nations mitigate their GHG reductions, adapt to climate change, and fulfill their Kyoto Protocol requirements (including their MMRV requirements). ${ }^{39}$ But reporting parameters are inconsistent, and developing nations allege that some Northern nations have repeatedly pledged aid that was never delivered. ${ }^{40}$

- Biodiversity conservation in the global South.

${ }^{30}$ UN-REDD Programme, Scope of Work-Towards a "Governance MRV Framework," Draft June 2009, at 3, http://europeandcis.undp.org/environment/sthelena/show/5979879F-F203-1EE9-B50CDC856DB6038E.

${ }^{31}$ BREIDENICH \& BoDANSKY, supra note 24, at 10, 14; Wettestad, supra note 25; Schmidt, supra note 12 , at $8,9$.

32 BrEIDENICH \& BoDANSKY, supra note 24 , at 14.

${ }^{33}$ Niederberger \& Kimble, supra note 15 , at $47,51$.

${ }^{34}$ E.g., Schmidt, supra note 12, at 3.

${ }^{35}$ Todd Stern, Special Envoy for Climate Change, "A New Paradigm: Climate Change Negotiations in the PostCopenhagen Era," Address at University of Michigan Law School (Oct. 8, 2010), http://www.state.gov/g/oes/rls/ remarks/2010/149429.htm; Bryan Walsh, At Cancún, a New Pragmatism in Climate Policy, Time, Dec. 13, 2010 , available at http://www.time.com/time/health/article/0,8599,2036642,00.html; Broder, supra note 20.

${ }^{36}$ BREIDENICH \& BODANSKY, supra note 24, at 1 .

${ }^{37}$ Bali Action Plan, supra note 10, at 8.

${ }^{38}$ WORLd ResourCes INSTITUTE, supra note 17 , at 16.

${ }^{39}$ BREIDENICH \& BodANSKY, supra note 24 , at 16. 
- Social and economic development goals for REDD+ in the global South. MMRV can also ensure that both the livelihoods of poor people-and the biodiversity and ecosystem services that form the basis of those livelihoods-are enhanced through REDD+. ${ }^{41}$ Thus conservation and pro-poor groups in both North and South call for MMRV of social and ecological safeguards for REDD+. If investors are going to appropriate (even with compensation) Southern forests, they will need to be accountable for protecting and ameliorating the livelihoods and basic rights of forest-dependent communities, and for protecting and enhancing the diverse species that live in tropical forests. ${ }^{42}$ So, for example, the Climate, Community \& Biodiversity Alliance (itself a coalition of NGOs, international research institutions, and business interests) has put together "REDD+ Social \& Environmental Standards" for individual projects, albeit with an eye toward having nations or subnational entities adopt these as uniform standards for all REDD+ programs in their jurisdiction. ${ }^{43}$ These standards safeguard local peoples' rights, ensure that local people (with special attention to indigenous peoples) are full and equal participants and beneficiaries in REDD+ projects, and that REDD+ projects maintain and enhance biodiversity and ecosystem services. ${ }^{44}$ The standards contain criteria and indicators that would allow results to be measured, monitored, reported, and verified. Of particular focus in the standards is a set of MMRV criteria for stakeholder participation in all phases of project management. ${ }^{45}$ And CCBA and other NGOs have put together a comprehensive Manual for Social Impact Assessment of Land-Based Carbon Projects, resulting in "REDD+ SES (Social and Environmental Safeguards)" to guarantee community and ecological co-benefits from REDD+ through naming measurable indicators and exploring how to monitor and verify that these indicators have been achieved. ${ }^{46}$

In forthcoming work, I analyze how MMRV shows ways to overcome a "crisis of mistrust", to promote cooperation in mitigating climate change, deforestation, and other pressing problems. I explain the goals and methods of REDD+ and the system of MMRV proposed to make massive infusions of cash for REDD+ feasible, effective, and equitable. MMRV symbolizes huge divides in power wielded by North/South, while simultaneously diminishing the power differential. While detailing various objections to the MMRV regime, I also show how implementing this regime can help us incorporate more voices with legal rights and

\footnotetext{
${ }^{40}$ Benito Müller, Is There Room for Compromise? The Debate on Institutional Arrangements for Climate Finance (Oxford Institute for Energy Studies) Oct. 2009, http://www.oxfordclimatepolicy.org/publications/documents/ comment_01_10_09.pdf; Martin Stadelmann, J. Timmons Roberts \& Axel Michaelowa, Keeping a Big Promise: Options for Baselines to Assess "New and Additional" Climate Finance, at 2 (CIS Working Paper No. 66, 2010).

${ }^{4 l}$ For a full accounting of what a maximally equitable REDD+ project would comprise, see Takacs, supra note 9; John Costenbader, REDD+ Benefit Sharing: A Comparative Assessment of Three National Policy APPROACHES (UN-REDD Programme 2010).

${ }^{42}$ E.g., International Institute for Environment and Development (IIED), Carbon Righteousness: How to Lever Pro-Poor BeneftTs from REDD+ (2011).

${ }^{43}$ http://www.redd-standards.org/.

${ }^{44} \mathrm{CCB}$, supra note 13; Takacs, supra note 9.

${ }^{45}$ See Nicholas Moss \& Ruth Nussbaum, A Review of Three REDD+ Safeguard Initiatives $15-16$ UNREDD Programme June (2011).

${ }^{46} \mathrm{CCB}$, supra note 13 , at 4-5 (listing what counts as social impacts).
} 
responsibilities into international law, re-envision what international law means by "sovereignty," and move us closer to the ideal of sovereign equality. Responding to a cascade of ecological stressors, MMRV for REDD+ proposes a process of negotiated cooperation that not only can help ward off multiple ecological disasters, but may present a model for how North and South may work together to address other environmental problems that threaten us all. 